\title{
Quality of models supplied to dental laboratories for the fabrication of partial removable denture framework
}

\author{
Qualidade de modelos enviados aos laboratórios para \\ execução de prótese parcialmente removível
}

\author{
Luma de Vasconcelos MENEZES ${ }^{1}$ iD https://orcid.org/0000-0001-7689-6163 \\ Thais Carine SILVA2 iD https://orcid.org/0000-0001-9878-6280 \\ Catia Maria Fonseca GUERRA ${ }^{1}$ iD https://orcid.org/0000-0002-6999-1514 \\ Renata CIMÕES² iD https://orcid.org/0000-0003-3673-8739 \\ Bruna de Carvalho Farias VAJGEL ${ }^{2}$ iD https://orcid.org/0000-0002-2756-0767
}

\begin{abstract}
Objective: The aim of this study was to evaluate the models and plannings of metallic framework of removable partial prosthesis sent to dental laboratories in the city of Recife. Methods: The physical and technical conditions of plaster models were sent by the dentists to 4 dental laboratories. All models were examined, photographed and recorded on a form according to the research objective. Results: A total number of 235 models sent by dental surgeons were used to prepare the metallic structure, in which none of the models presented surveying nor the path of insertion. Out of the 235 models, $41(17.44 \%)$ presented serious failures, such as positive and negative bubbles, broken dental elements, direct retainers and damaged edentulous areas. With respect to the planning, only 22 (9.35\%) models were presented with the metallic framework planning, but in an unsatisfactory way. Regarding mouth preparation, no model presented a guide plane, and only $6.8 \%$ of models had rests seats, but incorrectly prepared. Conclusion: The models evaluated presented poor quality, lack of planning and no mouth preparation. This shows the need for dental surgeons to be aware of the appropriate prosthesis models and plannings in order to ensure a satisfactory and long-term rehabilitation of the patient, as well as preserving the remaining mouth structures.
\end{abstract}

Indexing terms: Denturists. Planning. Removable partial prosthesis.

\section{RESUMO}

Objetivo: Avaliar os modelos e planejamentos das estruturas metálicas das próteses parciais removíveis enviadas aos laboratórios de prótese dentária da cidade do Recife. Métodos: Foram avaliadas as condições físicas e técnicas dos modelos de gesso enviados pelos dentistas à 4 laboratórios de prótese dentária. Todos os modelos foram examinados, fotografados e registrados por meio de um formulário de acordo com o objetivo da pesquisa. Avaliou-se 235 modelos enviados pelos cirurgiões dentistas para confecção

1 Universidade Federal de Pernambuco, Curso de Odontologia. Recife, PE, Brasil.

2 Universidade Federal de Pernambuco, Programa de Pós-Graduação em Odontologia. Av. Professor Moraes Rego, 1235, Cidade Universitária, 52670-901, Recife, PE, Brasil. Correspondence to: BCF VAJGEL. E-mail: <bruna_farias@hotmail.com>.

v $\mathbf{v}$ v

How to cite this article

Menezes LV, Silva TC, Guerra CMF, Cimões R, Vajgel BCF. Quality of models supplied to dental laboratories for the fabrication of partial removable denture framework. RGO, Rev Gaúch Odontol. 2020;68:e20200054. http://dx.doi.org/10.1590/1981-863720200005420180107 
da estrutura metálica, na qual nenhum dos modelos apresentou delineamento e registro do eixo de inserção. Resultados: Dos 235 modelos, 41 (17,44\%) apresentaram falhas graves, tais como bolhas positivas, bolhas negativas, elementos dentários quebrados, retentores diretos e áreas edêntulas danificados. Quanto ao planejamento, apenas 22 (9,35\%) modelos apresentavam-se com o desenho da estrutura metálica, porém, de maneira insatisfatória. Quanto ao preparo de boca, nenhum modelo apresentou preparo de plano guia, e apenas 6,8\% dos modelos possuíam nichos, porém confeccionados de maneira incorreta. Conclusão: Os modelos avaliados apresentaram qualidade insatisfatória, ausência de planejamento e realização de preparo de boca. Isto demonstra a necessidade de conscientização dos cirurgiões dentistas para a confecção dos modelos e planejamentos adequados das próteses, a fim de garantir uma reabilitação duradoura e satisfatória ao paciente, assim como proservação das estruturas bucais remanescentes.

Termos de indexação: Auxiliares de prótese dentária. Planejamento. Prótese parcial removível.

\section{INTRODUCTION}

The partial removable dental prosthesis (PRDP) is a treatment modality widely used nowadays [1]. In addition to the replacement of missing teeth, they aim to restore the patient's functional and, if possible, aesthetic properties, in addition to preserving the remaining structures and quality of life [2].

This device allows the rehabilitation of almost all edentulous area, it also recovers teeth and other absent structures, besides having versatility in indication and low laboratorial cost $[3,4]$. However, the aesthetic restoration obtained by this type of prosthesis is not desirable, especially because of the visualization of the elements that compose it [5].

Despite its great indication, it is important to evaluate the general health of the patient, the amount, disposition and size of the remaining teeth, the shape of the residual ridge, and knowledge about indications and types of elements that constitute the framework, since these variables can influence the rehabilitation plan of a PRDP [4].

To achieve the success of prosthetic treatment, the dental surgeon (DS) must perform a correct planning and pre-preparation of the remaining teeth. The technician is responsible for carrying out the laboratory steps, while the patient must follow all the instructions for using the PRDP, as well as its hygiene and regular dental appointments [3-6].

Research has been carried out in Brazil in order to evaluate the factors that could contribute to the failure of the PRDP. The causes most frequently associated with PRDP failure are: unsatisfactory diagnoses and treatment plans; Inadequate use of survey in the planning phase; Incorrect pre-treatment of the mouth; Communication failure between DS and laboratory; Laboratory failure for not following the drawing and instructions sent by the DS; Incorrect indications and drawings of clamps and connectors; Failure to provide adequate mucosal support for distal extension bases; Use of occlusal forms that do not fit with the remaining teeth; Lack of guidance for patients regarding the use of PRDP; And also of the patient in not accepting their responsibility in maintenance [2,7-9]. A well planned, pre-prepared, well-oriented and built PRDP may contribute to the preservation of the remaining teeth and supporting tissues. However, if the determination of the insertion trajectory, the design of the study models, the preparation of guide plans, the correction of the occlusal plane and even the construction of the rests seats are neglected or delegated to the dental technician (DT), it may cause damages to the masticatory apparatus, trauma or mobility of the teeth that support the prosthesis, contributing to the development of pathologies and promoting bad reactions, such as temporo-mandibular disorders $[3,6,10]$.

Despite the importance of planning by DS for the construction of the metal framework of the PRDP, there are no studies evaluating the condition of quality and planning of models sent to dental laboratories in the city of Recife. Therefore, the purpose of this work is to evaluate the physical conditions (quality of the model and type of plaster) and techniques (presence of planning, design, surveying and mouth preparation) of the works sent to the PRDP metal framework confection laboratories of Recife, Pernambuco.

\section{METHODS}

This study was carried out according to the Resolution of the National Health Council / CNS number 466/12, which establishes Directives and Regulatory Norms for Research involving Human Beings. The work was submitted to the Ethics and Research Committee of the Federal University of Pernambuco, and approved under No. 117210/2016, registered with the National Information System on Ethics in Research Involving Human Beings 
(SISNEP - CAAE 61856216.4.0000.5208). All laboratories that agreed to participate in the study signed the statement of consent letter with permission to use data.

The research was performed in 4 dental laboratories located Recife (PE) duly registered in the Regional Council of Dentistry, from January to April 2017. Only the plaster models and plans of partially edentulous patients were sent by DS for the construction of PRDP framework. Models used to make other prosthetic structures were excluded from the study.

The models were analyzed in a suitable environment under natural and artificial light and photographed with the NIKON D-3100 digital camera for recording and illustration of the work. For this, the evaluator used disposable gloves to avoid possible cross-contamination between the evaluated models. The methods used for data collection did not cause any damage or injury to the physical integrity of the models evaluated.

The models were evaluated and recorded in a form according to the research objectives and identified by numbers in sequential order of evaluation. The questionnaire was filled out by a single researcher previously prepared, consisting of eight questions: 1) type of arch (upper / lower); 2) Kennedy classification (I, II, III, IV); 3) type of material delivered to the laboratory (impression or model); 4) evaluation regarding execution and quality of mouth preparation (rests seats, guide plane); 5) whether or not PRDP planning was sent to the laboratory (paper drawing or model); 6) if the model was sent surveyed by the DS; 7) evaluation of the model sent (type of plaster); 8) quality of the submitted model (acceptable or unacceptable).

It is worth mentioning that despite the evaluation of whether or not sending the metallic framework plan, the present study did not aim to evaluate the correct indication of the types of clamps and major connectors planned by the DS.

The survey forms were pre-coded and checked for consistency of its completion. Then, the information collected was processed and stored in a database, through the Statistical Package of Social Science (SPSS) version 22.0, and analyzed through descriptive statistical methods.

\section{RESULTS}

A convenience sample of 235 plaster models from four prosthesis laboratories specialized in PRDP metal framework in Recife $(\mathrm{PE})$ were evaluated.
When evaluating the type of arch, it was observed that 118 models (50.21\%) were from the upper arch and 117 (49.79\%) from the lower arch. As to Kennedy's classification, a higher prevalence of partially edentulous class III arches (43.82\%) was observed, followed by class II (29.39\%), I (22.97\%), and IV (3.82\%). Regarding the modifications of Kennedy classifications, it was found that class III modification 1 (20.42\%) was more prevalent, followed by class II modification 1 (16.17\%), class III modification 2 (13.19\%) and Class II modification 2 $(5.95 \%)$ (table 1).

All models evaluated (100\%) were made with type IV plaster and had already been hollowed in the laboratories. However, we observed that no model was drawn by the dentist nor the path of insertion was recorded, and all responsibility was delegated to the DT (table 1).

Regarding the quality of the models, the great majority was considered acceptable (85.95\%). However, $18(7.65 \%)$ from the 235 models presented positive bubbles and $5(2.12 \%)$ negative bubbles. In addition, 11 models $(4.68 \%)$ came back with broken dental elements, in which 6 of these models the loose elements were to be glued by the laboratory, and in the other 5 models the broken material was not presented for bonding (figure 1). One model $(0.42 \%)$ had the dental element already glued by the DS, in 5 models $(2.12 \%)$ the direct retainers were damaged and 1 model $(0.42 \%)$ was damaged in the region of the edentulous area, where the saddle would be located (table 1).

As for the planning, no DS had sent to the laboratory the planning of the metallic framework design in a correct and complete way. Out of the 235 models evaluated, $17(7.23 \%)$ had unsatisfactory drawings and still made up in the working model, 4 (1.70\%) described only the major connector in the working model or paper, and 1 model (0.42\%) cited in the working model only the type of clamp to be used in a specific dental element (table 1).

Regarding mouth preparation, it was observed that most DS did not perform this procedure. Of the 235 models, the vast majority (219 models) did not show rests seats in any of its elements. Only 16 models (6.8\%) presented a rest seat, but were not considered correct regarding the format $(6.38 \%)$, dimension $(3.82 \%)$ and location (1.7\%). In addition, in 6 models (2.55\%) rests seats were not made in all indicated elements. Thus, no model presented itself with a rest seat made in all retainers 
in a correct way. Moreover, it should be noted that no model presented preparation of the guide plane, despite the visible need (table 1).

Table 1. Analysis of plaster models and planning sent to dental laboratories in Recife (PE).

\begin{tabular}{|c|c|c|}
\hline Variables & $\mathrm{n}$ & $\%$ \\
\hline \multicolumn{3}{|l|}{ Arch type } \\
\hline Superior & 118 & 50.21 \\
\hline Inferior & 117 & 49.79 \\
\hline \multicolumn{3}{|l|}{ Type of the template material } \\
\hline Type IV plaster & 235 & 100 \\
\hline Other & 0 & 0 \\
\hline \multicolumn{3}{|l|}{ Kennedy classification } \\
\hline Class I & 54 & 22.97 \\
\hline Class II & 69 & 29.39 \\
\hline Class III & 103 & 43.82 \\
\hline Class IV & 9 & 3.82 \\
\hline \multicolumn{3}{|l|}{ Material sent to the laboratory } \\
\hline Impression & 0 & 0 \\
\hline Model & 235 & 100 \\
\hline \multicolumn{3}{|l|}{ Presence of mouth preparation } \\
\hline No & 219 & 93.2 \\
\hline Yes & 16 & 6.8 \\
\hline \multicolumn{3}{|l|}{ Mouth preparation done } \\
\hline \multicolumn{3}{|l|}{ Guide plane } \\
\hline Yes & 0 & 0 \\
\hline No & 235 & 100 \\
\hline \multicolumn{3}{|l|}{ Rests seats } \\
\hline Yes & 16 & 6.8 \\
\hline No & 219 & 93.2 \\
\hline \multicolumn{3}{|l|}{ Planning dispatch } \\
\hline Not dispatched & 214 & 90.65 \\
\hline Unsatisfactory planning & 21 & 9.35 \\
\hline Satisfactory planning & 0 & 0 \\
\hline \multicolumn{3}{|l|}{ Insertion axis dispatch } \\
\hline Yes & 0 & 0 \\
\hline No & 235 & 100 \\
\hline \multicolumn{3}{|l|}{ Most frequent failures } \\
\hline Flawless templates & 194 & 82.59 \\
\hline Positive bubbles & 18 & 7.65 \\
\hline Negative bubbles & 5 & 2.12 \\
\hline Broken teeth & 11 & 4.68 \\
\hline Damaged retainers & 6 & 2.54 \\
\hline Damaged edentulous area & 1 & 0.42 \\
\hline TOTAL & 235 & 100 \\
\hline
\end{tabular}

\section{DISCUSSION}

The results of the present study show the neglect of the DS in the planning and mouth preparation of the
PRDP, corroborating with other studies carried out in São Paulo, Porto Alegre, Piauí, Bahia, Paraíba and Goiás $[2,3,6,10-15]$. This research is the first to evaluate the quality of models and plans sent to the laboratories in Recife-PE.

Almost all models evaluated did not present any type of design or planning of the metallic framework, while those who presented had the planning to be considered incomplete or with scratches in the working model, suggesting the drawing of the metallic framework in an erroneous way. Corroborating with Batista et al. [6], $88.1 \%$ of the models sent by dentists to laboratories in João Pessoa-PB did not have any sketches that indicated the planning of the future metallic framework. In other studies carried out in Brazil, in the cities of Teresina, São Paulo and Belém, the DS also did not perform the planning and design of the prosthesis in most of the models sent to the laboratories, with rates ranging from $75 \%$ to $94.29 \%$ $[2,3]$.

In the models examined, no professional demarcated the bearing area, which indicates to the prosthetist how far to extend the base of the prosthesis. In the absence of planning by the DS, the DT is delegated the main function of determining which components of the PRDP are ideal for rehabilitating each case, and it is an ethical infraction to delegate, to professional or auxiliary professionals, exclusive acts or attributions of the surgeon [16]. Similar to that found in Porto Alegre, where only $3 \%$ of the professionals performed this demarcation [12].

The numbers are also alarming with regard to the use of surveyors, since in none of the analyzed models were there information about the path of insertion and removal determined for the process of making the PRDP. Facts already reported since the 70's and still present stated that the design is often neglected by DS and delegated to the DT [6-14]. Leading to believe that there is still a lack of awareness on the part of DS and DT.

In order to perform the laboratory procedures of a future metal framework well adapted to the mouth, a precise working model is necessary and that this does not suffer wear. In the present research, all molds were hollowed with type IV plaster, ideally recommended for better reproduction of details [17]. These results are more favorable than that found by Duarte [16], who found a greater number of models made with type II plaster (54.2\%). The use of ordinary plaster is very harmful to prepare the 
working models due to its high degree of dimensional change and passivity to wear during its handling $[10,15]$.

Regarding the plaster hollow site, all of the models analyzed in the study have already been hollowed in laboratories. However, it differs from that observed by Duarte [11], where $43.7 \%$ of the models were sent to be hollowed in laboratories.

The presence of positive and negative bubbles, as well as the broken dental elements in the models evaluated in the present study, indicates the lack of care with the molding and casting procedures of the models, corroborating with the negligence committed by the DS during the dispatch of works to the framework of PRDP making procedure. Other studies confirm these findings and considered the high index of models with structural defects (85\%) alarming, and the low quality of the models may affect the quality of the prosthesis obtained $[6,8]$.

Regarding the mouth preparation observed in the models sent to the laboratories, only 16 models had a rest seat, but they were made with at least inappropriate size, dimension or location. Thus, no model presented correctly made rests seat in all the elements that needed the preparation. In addition, none of the evaluated models presented evidence of retention making and preparation of guide plane, despite the necessity. These results are in agreement with surveys carried out in other Brazilian cities $[11,12,15]$. Where they reported never having received models with prepared rests seats. These mouth preparations aim to neutralize the horizontal forces generated at the time of insertion and removal of the prosthesis, as well as to direct the occlusal loads generated during mastication in a direction parallel to the long axis of the supporting teeth, being this procedure important to preserve the remaining dental structures and longevity of the work [10].

It was concluded, therefore, that the models evaluated in Recife-PE presented an unsatisfactory quality and lack of planning and mouth preparation. It demonstrates the need for awareness of the DS for the adequate accomplishment of models confection and prosthesis planning in order to guarantee a long lasting and satisfactory rehabilitation for the patient, as well as, preservation of the remaining buccal structures.

\section{CONCLUSION}

The models evaluated presented an unsatisfactory quality and lack of planning and mouth preparation.
Indicating that the need for awareness about the MD for adequate rehabilitation for the patient, allowing the preservation of other oral structures.

\section{Collaborators}

LV MENEZES, execution of methodology and writing the manuscript. TC SILVA, writing the manuscript and submission for publication. CMF GUERRA, such as the concept and design. $R$ CIMÕES, analysis and interpretation of the data. BCF VAJGEL, such as the concept and design and project coordination.

\section{REFERENCES}

1. Singh BP, Gauthier G, Rompre P, Grandmont P De, Emami E. A 30-Year Follow-Up of Partial Removable Dental Prostheses in a University Dental School Setting. J Prosthodont. 2015;0:13-6. https://doi.org/10.1111/jopr.12336

2. Palomo E, Stegun MLTRC. Avaliação do Comportamento dos cirurgiões-dentistas e protéticos na confecção de estruturas metálicas de próteses parciais removíveis nos laboratórios comerciais da cidade. Rev Bras Prótese Clin Lab. 2003;5(27):425-31.

3. Castro JCO, Zanetti RV, Feltrin PP, Froner EE, Moura CDVS de. Modelos de prótese parcial removível e comunicação entre cirurgiões-dentistas e técnicos nos laboratórios na cidade de Teresina, Piauí 1. RGO, Rev Gaúch Odontol. 2009;57:273-9.

4. Rezende LVL, Pellizzer EP, Verri FR, Pereira JA, Rezende RM de O. Influência do formato do rebordo alveolar sagital em reabilitações com associação de prótese parcial removível de extremidade livre e implante ósseo integrado. Oral Sci. 2011;3:12-20.

5. Cerutti-Kopplin D, Emami E, Hilgert JB, Hugo FN, Rivaldo E, Padilha DP. Predictors of satisfaction with dentures in a cohort of individuals wearing old dentures: functional quality or patient-reported measures ? J Prosthodont. 2015;1-5. https:// doi.org/10.1111/jopr.12383.

6. Batista AUD, Sales JPLA, Neto AF, Carreiro A da FP. Avaliação do planejamento de prótese parcial removível em modelos recebidos por laboratórios de João Pessoa, PB. Pesq Bras Odontoped Clin Integr. 2011;11:53-8. https:// doi: 10.4034/ PBOCI.2011.111.08

7. Meyer GA, Schindler JM, Urbanetto CR, Leon BLT. Avaliação dos planejamentos realizados por técnicos em próteses dentárias em modelos classe I de Kennedy. Rev Bahiana Odontol. 2012;3(1): 26-36.

8. Kliemann C, Oliveira W. Manual prótese parcial removível. São Paulo: Artes Médicas; 2002.

9. Araujo TP, Gonçalves CJS, Bezerra ALT, Cruz DF DA, Fernandez ML, Mukai MK, et al. Prevalência dos tipos de arcos desdentados, preparo de boca e qualidade dos modelos para próteses removíveis na Paraíba. Rev Bras Ciências Saúde. 2012;16:213-8. https://doi:10.4034/RBCS.2012.16.02.13 
10. Duarte ARC, Paiva HJ. Avaliação do nível de conhecimento e conscientização do cirurgião-dentista e do técnico em prótese dental, em relação ao planejamento e a execução de próteses parciais removíveis: estudo laboratorial. Rev $A B O$ Nac. 2000;8(4):232-7.

11. Fernandes EL, Rivaldo EG, Cosme DC, et al: Avaliação do material enviado aos cirurgiões dentistas aos laboratórios de próteses para confecção de prótese parciais removíveis. Rev Fac Odonto. 2004;45 (2):14-16. https://doi.org/10.22456/2177-0 018.7658

12. Oliveira MCS, Santos LB, Vieira AC, Sampaio NM, Oliveira VMB. Prevalência do planejamneto em prótese parcial removivel na cidade de Feira de Santana, Bahia, Brasil. Int J Dent. 2009;2:67-71.

13. Ribeiro CF, Melo AUC DE, Júnior AADA, Oliveira JLG DE, Araújo VP DE, Neves ACC. Relação cirurgião-dentista/ laboratório de prótese dentária: quem realiza o planejamento das armações metálicas das próteses parciais removíveis? Rev
Bras Ciências Saúde. 2012;16:525-30. http:// doi:10.4034/ RBCS.2012.16.04.05

14. Alencar GX, Pedrosa MS, Lopes LDS. Avaliação do planejamento em modelos para próteses parciais removíveis recebidos por laboratórios de Teresina, Piauí. Salusvita. 2016;35:423-35.

15. Brasil. Conselho Regional de Odontologia. Código de Ética. Resolução CFO n. 118/2012 [citado 2018 Jul 11]. Disponível em: <http://cfo.org.br/wp-content/uploads/2009/09/codigo_ etica.pdf. Acesso em 11/07/2018>.

16. Dias SC, Ávila GB, Panzeri H, Moisés MR, Ribeiro JCR, Ribeiro $J G R$, et al. Análise da capacidade de reprodução de detalhes expressa por diferentes materiais de modelagem. Arq Odontol. 2007; 43(4): 137-43.

Received on: 20/12/2018

Final version resubmitted on: 22/4/2019

Approved on: 23/6/2019 